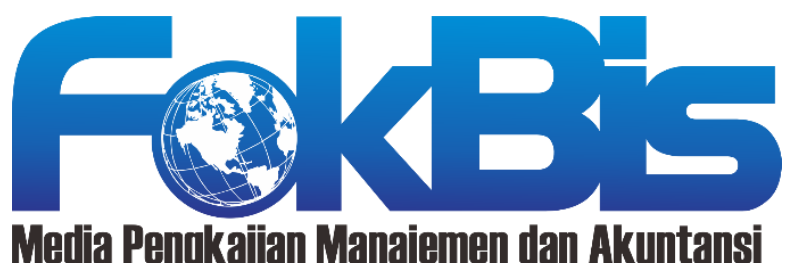

http://journal.stieputrabangsa.ac.id/index.php/fokbis/index

ISSN: 2623-2480/ P-ISSN: 1693-5209

\section{Peran Risiko Sanksi Pajak pada Pengaruh Good Governance dan Whistleblowing System Terhadap Kepatuhan Wajib Pajak}

\author{
M. Rizki Utama ${ }^{1)}$, Amir Hidayatulloh ${ }^{2)}$ \\ 1,2) Universitas Ahmad Dahlan, Yogyakarta \\ email: ${ }^{1)}$ rizkiutama572@gmail.com, ${ }^{2)}$ amir.hidayatulloh@act.uad.ac.id
}

\section{Article Information}

\section{History of Article:}

Received: May $8^{\text {th }} 2020$

Accepted: July $3^{\text {rd }} 2020$

Published: July $31^{\text {st }} 2020$

\section{DOI:}

10.32639/fokusbisnis.v19i1.540

\begin{abstract}
ABSTRAK
Tujuan penelitian ini adalah untuk menganalis pengaruh good governance dan whistleblowing system terhadap kepatuhan wajib pajak. Selain itu, penelitian ini juga untuk menganalis pengaruh good governance dan whistleblowing system terhadap kepatuhan wajib pajak jika dimoderasi oleh risiko sanksi pajak. Responden dalam penelitian ini berjumlah 104 responden yang berasal dari 22 propinsi. Teknik pengambilan sampel dalam penelitian ini menggunakan purposive sampling, dengan kriteria wajib pajak orang pribadi yang memiliki NPWP. Teknik analisis data dalam penelitian ini menggunakan Partial Least Square dengan bantuan alat WarpPLS. Penelitian ini memperoleh hasil bahwa kepatuhan wajib pajak dipengaruhi oleh good governance dan whistleblowing system. Akan tetapi, penelitian ini tidak dapat membuktikan bahwa risiko sanksi pajak memoderasi pengaruh good governance dan whistleblowing system terhadap kepatuhan pajak. Hal ini karena risiko sanksi pajak merupakan salah satu variabel independen yang dapat memengaruhi kepatuhan wajib pajak.
\end{abstract}

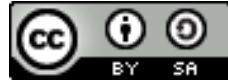

Kata Kunci: Kepatuhan Wajib Pajak; Good Governance; Whistleblowing System; Risiko Sanksi Pajak

\begin{abstract}
The purpose of this study was to analyze the effect of good governance and whistleblowing systems on taxpayer compliance. In addition, this study also analyze the effect of good governance and whistleblowing systems on taxpayer compliance if moderated by the risk of tax sanctions. Respondents in this study amouted 104 respondents from 22 provinces. The sampling technique in this study uses purposive sampling, with criteria of individual taxpayers who have an NPWP. The data analyzes technique in this study used Partial Least Square (PLS) with the help of the WarpPLS tool. This study obtained result that taxpayer compliance is influenced by good governance and whistleblowing system. However, this study cannot prove that the risk of tax sanction moderates the effect of good governance and whistleblowing system on tax compliance. This is because the risk of tax sanction is one of the independents variables that can affect taxpayer compliance.
\end{abstract}

Keywords: Kepatuhan Wajib Pajak; Good Governance; Whistleblowing System; Risiko Sanksi Pajak 


\section{PENDAHULUAN}

Pajak merupakan kontribusi wajib dari warga negara kepada Negara yang pemungutannya didasarkan pada undang-undang, tidak mendapatkan imbalan secara langsung, dan digunakan untuk kepentingan Negara bagi kemakmuran rakyat sebesar-besarnya (Undang-undang Nomor 28, 2007). Pajak memiliki dua fungsi yaitu fungsi mengatur dan fungsi anggaran. Fungsi mengatur berarti pajak digunakan sebagai alat untuk mengatur kegiatan ekonomi dan sosial. Sedangkan, fungsi anggaran berarti pajak digunakan sebagai salah satu sumber anggaran pemerintah, baik pemerintah pusat maupun pemerintah daerah (Mardiasmo, 2009).

Pada tahun 2018, penerimaan Negara didominasi oleh sektor pajak. Hal ini terlihat dari sebesar 85,4 anggaran pendapatan dan belanja negara berasal dari pajak (APBN, 2018). Sehingga, hal ini mengindikasikan bahwa pajak memiliki peran yang sangat penting dalam penerimaan Negara. Namun, realisasi penerimaan Negara dari tahun 2013-2017 selalu tidak memenuhi target yang telah ditetapkan sebelumnya. Hal ini terlihat dari data yang disajikan pada (Laporan Kinerja Direktorat Jendral Pajak, 2017), berikut realisasi penerimaan pajak pada tahun 2013-2017.

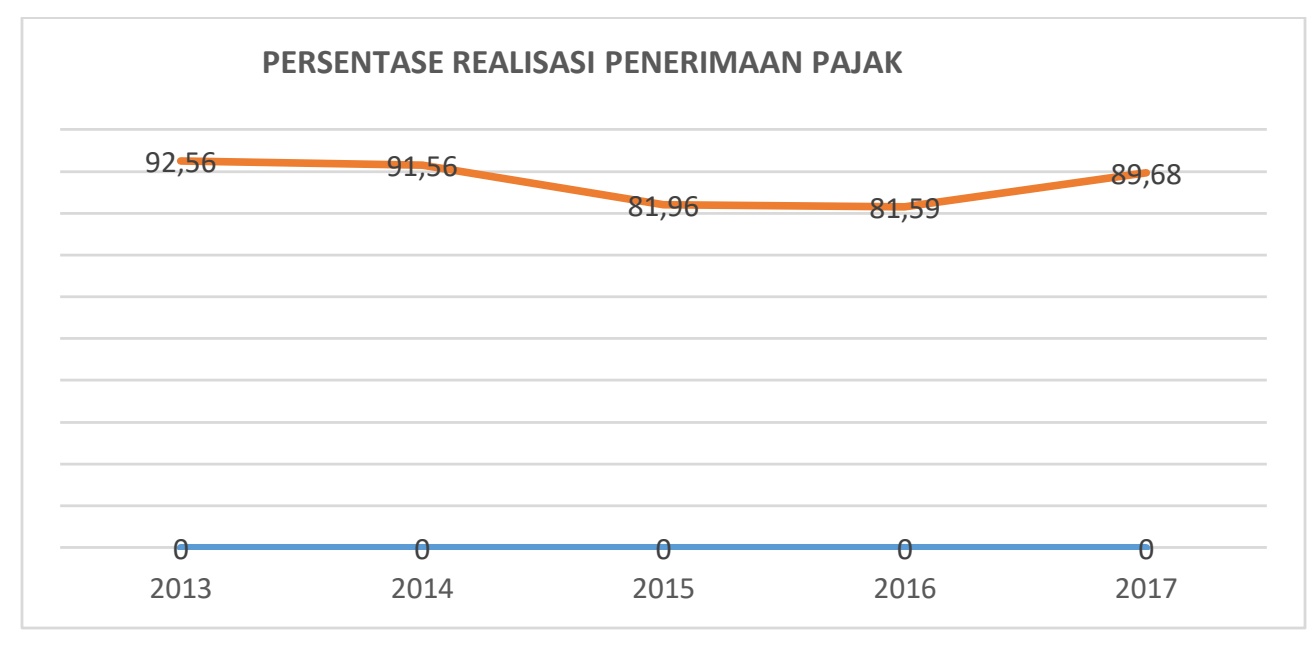

Gambar 1. Persentase Realisasi Penerimaan Pajak Tahun 2013-2017

Gambar 1 mengungkapkan data bahwa penerimaan pajak pada tahun 2013 sampai dengan 2017 selalu dibawah target yang telah ditetapkan sebelumnya. Persentase realisasi penerimaan pajak tertinggi yaitu pada tahun 2013 (92,36 persen). Sedangkan tahun 2017, persentase realisasi penerimaan pajak adalah 89,68 persen.

Berdasarkan pernyataan Menteri Keuangan bahwa Produk Domestik Bruto (PDB) atau tax ratio Indonesia masih tertinggal dibandingkan dengan Negara lain. Hal ini berdasarkan hasil audit yang dilakukan oleh Badan Pemeriksa Keuangan (BPK) pada tahun 2017, tax ratio Indonesia 10,78 persen (Putra, 2018). Indonesia menerapkan tiga sistem pemungutan pajak yaitu self assessment system, official assessment system, dan with holding system (Purwono, 2010). Pajak penghasilan merupakan salah satu yang menerapkan sistem pemungutan pajak self assesemnet system, wajib pajak diberi wewenang untuk menghitung, melaporkan, dan membayar pajaknya sendiri. Sehingga, self assessment system menuntut wajib pajak bersikap aktif (Mardiasmo, 2009).

Salah satu penyebab rendahnya kepatuhan pajak di Indonesia adalah banyaknya kasus penyelewengan pajak. Kasus penyelewengan tersebut menimbulkan rasa khawatir dalam diri wajib pajak bahwa pajak yang telah dibayarkan akan disalahgunakan atau digunakan sebagaimana tidak semestinya (Fahmi, 
2018). Menurut (Mardiasmo, 2009), minimal pemerintah harus memiliki tiga kriteria agar disebut pemerintah yang baik, yaitu transparasi, akuntabilitas publik, value for money (meliputi economy, efficiency, dan effectiveness). Pemerintah menerbitkan (Peraturan Direktur Jenderal Pajak Nomor PER22/PJ/, 2011) dalam rangka untuk mencegah dan melakukan deteksi dini atas pelanggaran yang mungkin terjadi di lingkungan Direktorat Jenderal pajak (DJP) melalui peningkatan peran pegawai serta masyarakat secara aktif untuk menjadi pelapor sebuah pelanggaran (whistleblower).

Beberapa penelitian sudah menguji faktor yang memengaruhi kepatuhan wajib pajak. Beberapa penelitian menemukan bahwa kepatuhan wajib pajak dipengaruhi oleh good governance (Kembaren \& Gunandi, 2013); (Khaerunnisa \& Wiratno, 2014); (Sulistyowati \& Pahlevi, 2018), whistleblowing system (Khulsum, 2014); (Sulistyowati \& Pahlevi, 2018); sanksi perpajakan (Irmawati \& Hidayatulloh, 2019); (Karnedi \& Hidayatulloh, 2019); (Pebrina \& Hidayatulloh, 2020).

Penelitian ini merupakan replikasi dari (Sulistyowati \& Pahlevi, 2018), yang meneliti pengaruh good governance dan whistleblowing system dengan risiko sanksi pajak sebagai variabel moderisasi di kabupaten Sleman. Sedangkan, penelitian ini menggunakan sampel di seluruh Indonesia. Hal ini agar hasil yang diperoleh dapat lebih digeneralisasi.

\section{KAJIAN LITERATUR DAN PENGEMBANGAN HIPOTESIS}

\section{Kepatuhan Pajak}

Kepatuhan wajib pajak adalah suatu sikap atau perilaku seorang wajib pajak yang melaksanakan semua kewajiban perpajakannya dan menikmati semua hak perpajakannya sesuai dengan ketentuan peraturan perundang-undangan yang berlaku (Restu, 2014 dalam (Putra \& Aryani, 2018). Sedangkan, (Mangoting \& Sadjiarto, 2013) mendefinisikan kepatuhan wajib pajak sebagai keadaan saat wajib pajak memenuhi semua kewajiban dan hak perpajakannya.

\section{Good Governance}

Menurut (Peraturan Pemerintah Nomor. 101, 2000), good governance atau pemerintah yang baik merupakan pemerintahan yang mengembangkan dan menerapkan prinsip-prinsip profesionalitas, akuntabilitas, transparansi, pelayanan prima, demokrasi, efisiensi, efektivitas, supremasi hukum dan dapat diterima oleh seluruh masyarakat. Menurut (Mardiasmo, 2016), ada beberapa karakteristik yang diberikan oleh United Nations Devolepment Programme (UNDP) dalam pelaksanaan good governance antara lain yaitu partisipasi, peran hukum, transparansi, responsif, orentasi konsensus, keadilan, efisiensi dan efektivitas, akuntabilitas, dan visi strategis. Namun, ada tiga dari delapan karakteristik yang diberikan oleh UNDP yang bisa dilakukan oleh akuntansi sektor publik yaitu transparansi, akuntabilitas, serta satu elemen value for money (economy, efficiency, dan effectiveness).

\section{Whistleblowing System}

Menurut (Peraturan Menteri Pendayagunaan Aparatur Negara dan Reformasi Birokrasi Republik Indonesia No 20, 2010), whistleblowing system merupakan mekanisme penyampaian pengaduan dugaan tindak pidana korupsi yang telah terjadi atau akan terjadi yang melibatkan pegawai dan orang lain yang terkait dengan dugaan tindak pidana korupsi yang dilakukan pada organisasi tempatnya bekerja. Sementara itu, pihak pengadu (whistleblower) adalah seseorang yang melaporkan perbuatan yang terindikasi tindak pidana korupsi yang terjadi pada organisasi tempatnya bekerja, atau pihak terkait lainnya yang memiliki akses informasi yang memadai atas terjadinya indikasi tindak pidana korupsi tersebut. 


\section{Risiko Sanksi Pajak}

Menurut (Siringoringo, 2015), risiko sanksi pajak merupakan suatu sanksi yang akan diterima apabila wajib pajak tidak patuh terhadap pelaksanaan kewajiban perpajakannya, dan sebaliknya. Risiko sanksi pajak tidak akan diterima apabila wajib pajak tersebut melaksanakan kewajiban perpajakannya sesuai dengan peraturan perpajakan yang berlaku.

\section{Pengembangan Hipotesis}

Dari uraian latar belakang dan kajian literatur maka rerangka penelitian ini adalah sebagai berikut:

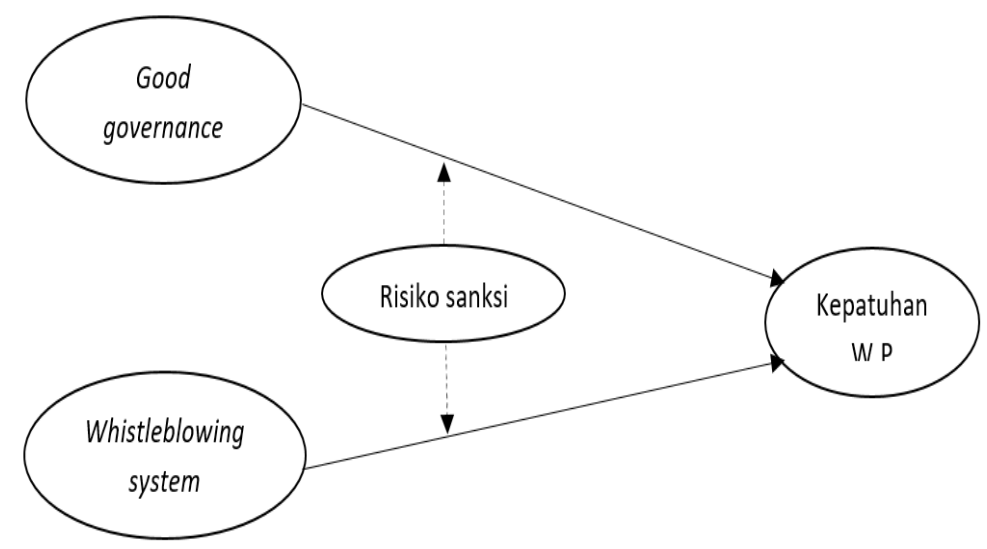

Gambar 2. Rerangka Penelitian

\section{Pengaruh Good Governance Terhadap Kepatuhan Wajib Pajak}

Menurut (Mardiasmo, 2016), good governance sering diartikan sebagai kepemerintahan yang baik. Minimal terdiri dari tiga hal dari delapan karakteristik yang diberikan oleh UNDP yang dapat dilakukan oleh akuntansi sektor publik yaitu transparasi, akuntabilitas publik, serta satu elemen value for money (economy, efficiency, dan effectiveness). Oleh karena itu, dengan adanya sistem pemerintahan yang baik akan meningkatkan kepatuhan wajib pajak. Hal ini karena meningkatnya kepercayaan wajib pajak terhadap apa yang dilakukan pemerintah. Pernyataan ini didukung oleh hasil penelitian (Kembaren \& Gunandi, 2013); (Khaerunnisa \& Wiratno, 2014); (Sulistyowati \& Pahlevi, 2018) yang menyatakan bahwa good governance berpengaruh terhadap kepatuhan wajib pajak. Dari uraian sebelumnya, maka hipotesis pertama $\left(\mathrm{H}_{1}\right)$ penelitian ini adalah sebagai berikut:

\section{$\mathrm{H}_{1}$ : Good governance berpengaruh terhadap kepatuhan wajib pajak}

\section{Pengaruh Whistleblowing System Terhadap Kepatuhan Wajib Pajak}

Dalam rangka mencegah dan melakukan deteksi dini atas pelanggaran yang mungkin terjadi pada lingkungan Direktorat Jenderal Pajak (DJP) melalui peningkatan peran serta pegawai dan masyarakat secara aktif untuk menjadi pelapor pelanggaran (whistleblower), DJP telah menerbitkan Peraturan Direktur Jenderal Pajak Nomor Per-22/PJ/2011 tanggal 19 Agustus 2011 tentang kewajiban melaporkan dan penanganan pelaporan pelanggaran (whistleblowing) di lingkungan Direktur Jenderal Pajak (Peraturan Direktur Jenderal Pajak Nomor PER-22/PJ/, 2011). Berdasarkan hasil penelitian (Siringoringo, 2015); (Sulistyowati \& Pahlevi, 2018), penerapan whistleblowing system di lingkungan DJP memiliki pengaruh terhadap kepatuhan wajib pajak. Dengan adanya Peraturan Direktur Jenderal Pajak Nomor PER22/PJ/2011 tersebut berarti menegaskan bahwa wajib pajak berperan aktif untuk melaporkan apabila terjadi kecurangan di lingkungan Direktorat Jenderal Pajak. Oleh karena itu, dengan adanya peraturan tersebut akan meningkatkan kepatuhan pajak dan mengurangi kecurangan. Dari uraian sebelumnya, maka hipotesis kedua $\left(\mathrm{H}_{2}\right)$ penelitian ini adalah sebagai berikut:

$\mathrm{H}_{2}$ : Whistleblowing system berpengaruh terhadap kepatuhan wajib pajak 
Pengaruh Good Governance Terhadap Kepatuhan Wajib Pajak Jika dimoderasi Oleh Variabel Risiko Sanksi Pajak

Menurut (Mardiasmo, 2016), good governance sering diartikan sebagai kepemerintahan yang baik. Sehingga, adanya sistem kepemerintahan yang baik berarti penengakan hukum juga diberikan secara tegas dan baik pada tindak kecurangan apapun. Sehingga, hal ini akan meningkatkan kepatuhan wajib pajak. Hasil penelitian (Siringoringo, 2015) mengungkapkan bahwa terdapat pengaruh antara penerapan good governance terhadap kepatuhan wajib pajak jika dimoderasi oleh variabel risiko sanksi pajak. Dari uraian sebelumnya, maka hipotesis ketiga $\left(\mathrm{H}_{3}\right)$ penelitian ini adalah sebagai berikut:

H3: Good governance berpengaruh terhadap kepatuhan wajib pajak jika dimoderasi oleh variabel risiko sanksi pajak

Pengaruh Whistleblowing System Terhadap Kepatuhan Wajib Pajak Jika dimoderasi Oleh Variabel Risiko Sanksi Pajak

Direktorat Jenderal Pajak (DJP menerbitkan Peraturan Direktur Jenderal Pajak Nomor PER 22/PJ/2011 bertujuan untuk mencegah dan mendeteksi dini atas pelanggaran yang mungkin terjadi di lingkungan DJP. Hal ini dilakukan dengan peningkatan peran serta pegawai dan masyarakat secara aktif untuk menjadi pelapor pelanggaran (whistleblower). Sistem pelaporan dan penanganan pelaporan yang tepat di likungan DJP diharapkan dapat meningkatkan pelaporan pelanggaran. Selain itu, sistem pelaporan dan penanganan pelaporan yang tepat di lingkungan akan mencegah rasa ingin berbuat curang ataupun melakukan penggelapan pajak di lingkungan DJP. Hal ini karena penegakan hukum juga pasti akan diberikan secara tegas dan baik sehingga kepatuhan wajib pajak pun meningkat. Pernyataan ini sesuai dengan hasil penelitian (Sulistyowati \& Pahlevi, 2018) yang menyatakan terdapat pengaruh penerapan whistleblowing system terhadap kepatuhan wajib pajak jika dimoderiasi oleh variabel risiko sanksi pajak. Dari uraian sebelumnnya, maka hipotesis keempat $\left(\mathrm{H}_{4}\right)$ penelitian ini adalah sebagai berikut:

$\mathrm{H}_{4}$ : Whistleblowing system berpengaruh terhadap kepatuhan wajib pajak jika dimoderasi oleh variabel risiko sanksi pajak.

\section{METODE}

Jenis penelitian ini adalah penelitian kuantitatif. Data yang digunakan dalam penelitian ini adalah data primer yang dibagikan melalui kuesioner. Kuesioner dibagikan secara online dengan bantuan google form. Populasi dalam penelitian ini adalah wajib pajak orang pribadi di Indonesia. Teknik pengambilan sampel dalam penelitian ini menggunakan purposive sampling, dengan kriteria wajib pajak orang pribadi yang memiliki NPWP. Sehingga, sampel dalam penelitian ini adalah wajib pajak orang pribadi yang memiliki NPWP.

Variabel dalam penelitan ini terdiri dari variabel independen, variabel dependen, dan variabel moderasi. Variabel independen dalam penelitian ini adalah good governance dan whistleblowing system. Variabel dependen dalam penelitian ini adalah kepatuhan wajib pajak orang pribadi. Sedangkan, variabel moderasi dalam penelitian ini adalah risiko sanksi pajak.

Kepatuhan wajib pajak didefinisikan sebagai keadaan saat wajib pajak memenuhi semua kewajiban dan hak perpajakannya (Mangoting \& Sadjiarto, 2013). Kepatuhan wajib pajak diukur dengan menggunakan delapan item pernyataan yang diadopsi dari (Sulistyowati \& Pahlevi, 2018) dengan menggunakan skala likert lima poin yaitu sangat tidak setuju (1), tidak setuju (2), netral (3) setuju (4) dan sangat setuju (5).

Menurut (Peraturan Pemerintah Nomor. 101, 2000), good governance didefinisikan sebagai pemerintahan yang mengembangkan dan menerapkan prinsip profesionalitas, akuntabilitas, transparasi, pelayanan prima, demokrasi, efisiensi, efektivitas, supremasi hukum, dan dapat diterima oleh seluruh masyarakat. Good governance diukur dengan menggunakan tujuh item pernyataan yang diadopsi dari 
(Sulistyowati \& Pahlevi, 2018) dengan menggunakan skala likert lima poin yaitu sangat tidak setuju (1), tidak setuju (2), netral (3) setuju (4) dan sangat setuju (5).

Risiko sanksi pajak merupakan suatu sanksi yang akan diterima apabila wajib pajak tidak patuh terhadap pelaksanaan kewajiban perpajakannya, dan sebaliknya sanksi tersebut tidak akan diterima apabila wajib pajak melaksanakan kewajiban perpajakannya sesuai dengan peraturan perpajakan yang berlaku (Siringoringo, 2015). Risiko sanksi pajak diukur dengan menggunakan Sembilan item pernyataan yang diadopsi dari (Sulistyowati \& Pahlevi, 2018) dengan menggunakan skala likert lima poin yaitu sangat tidak setuju (1), tidak setuju (2), netral (3) setuju (4) dan sangat setuju (5). Teknik analisis data dalam penelitian ini menggunakan Partial Least Square (PLS), dengan alat WarpPLS.

\section{HASIL DAN PEMBAHASAN}

Responden dalam penelitian berjumlah 104 responden. Deskripsi responden secara rinci disajikan pada tabel 1.

Tabel 1. Deskripsi Responden

\begin{tabular}{|c|c|c|}
\hline Deskripsi & Keterangan & Jumlah \\
\hline \multirow[t]{2}{*}{ Jenis Kelamin } & Laki-Laki & 59 \\
\hline & Perempuan & 45 \\
\hline \multirow[t]{9}{*}{ Usia } & 20-25 tahun & 37 \\
\hline & 26-30 tahun & 17 \\
\hline & 31-35 tahun & 13 \\
\hline & 36-40 tahun & 10 \\
\hline & 41-45 tahun & 7 \\
\hline & 46-50 tahun & 12 \\
\hline & 51-55 tahun & 4 \\
\hline & 56-60 tahun & 3 \\
\hline & 61-65 tahun & 1 \\
\hline \multirow[t]{4}{*}{ Tingkat Pendidikan } & SMA & 15 \\
\hline & Diploma & 14 \\
\hline & Strata 1 (S-1) & 74 \\
\hline & Strata 2/Strata 3 (S2/S3) & 1 \\
\hline \multirow[t]{14}{*}{ Domisili } & Jambi & 1 \\
\hline & Riau & 2 \\
\hline & Sumatera Selatan & 1 \\
\hline & Bangka Belitung & 1 \\
\hline & Lampung & 2 \\
\hline & Banten & 2 \\
\hline & D.K.I Jakarta & 8 \\
\hline & Jawa barat & 4 \\
\hline & Jawa Tengah & 5 \\
\hline & Jawa Timur & 9 \\
\hline & D.I.Y & 17 \\
\hline & Kalimatan Barat & 2 \\
\hline & Kalimatan Tengah & 2 \\
\hline & Kalimatan Selatan & 3 \\
\hline
\end{tabular}




\begin{tabular}{ll} 
Sulawesi Selatan & 8 \\
Gorontalo & 1 \\
Maluku Utara & 2 \\
Bali & 3 \\
NTB & 25 \\
NTT & 2 \\
Papua & 1 \\
Papua Barat & 3 \\
\hline
\end{tabular}

Sumber: data primer, diolah (2019)

Tabel 1 menunjukan bahwa responden dalam penelitian didominasi oleh responden berjenis kelamin lakilaki (59 responden). Usia responden didominasi oleh 20-25 tahun (27 responden). Pendidikan responden didominasi oleh strata 1 (S-1) yaitu sebanyak 74 responden. Responden dalam penelitian berasal dari 22 propinsi yang berada di Indonesia. Responden penelitian ini didominasi dari propinsi NTB, yaitu 25 responden.

Teknik analisis data dalam penelitian menggunakan Partial Least Square (PLS) dengan bantuan alat WarpPLS. Hasil analisis data dalam penelitian ini disajikan pada gambar 3.

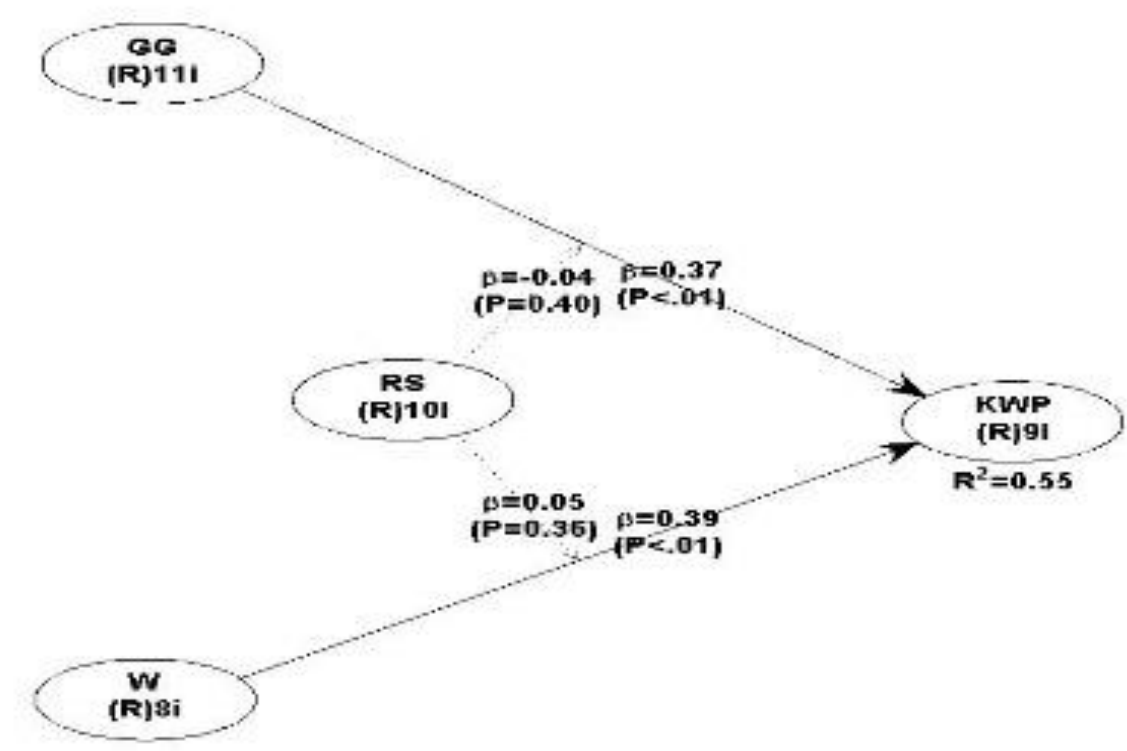

Gambar 3. Hasil Analisis Data

Sumber: data primer, diolah (2019)

Gambar 3 menunjukan nilai R-Square 0,55. Hal ini berarti bahwa variabel good governance dan whistleblowing system dapat menjelaskan variabel kepatuhan wajib sebesar 55 persen, sedangkan 45 persen variabel kepatuhan wajib pajak dijelaskan oleh variabel lain di luar model.

Good governance berpengaruh terhadap kepatuhan wajib pajak. Hal ini ditunjukan dengan nilai signifikasi $(<0,01)$ yang lebih kecil dibandingkan dengan 0,05. Atau dengan kata lain, hipotesis pertama $\left(H_{1}\right)$ penelitian ini terdukung. Hal ini berarti bahwa dengan diterapkannya sistem pemerintah yang baik, 
berupa transparasi, akuntabilitas publik, dan value for money akan berdampak pada peningkatan kepatuhan wajib pajak. Hal ini disebabkan karena dengan meningkatnya kepercayaan pada apa yang dilakukan oleh pemerintah. Hasil ini diperkuat dengan hasil sebelumnya (Kembaren \& Gunandi, 2013); (Khaerunnisa \& Wiratno, 2014); (Sulistyowati \& Pahlevi, 2018).

Gambar 3 juga menunjukan bahwa whistleblowing system berpengaruh terhadap kepatuhan wajib pajak. Hal ini ditunjukan dengan nilai signifikasi $(<0,01)$ yang lebih kecil dibandingkan dengan 0,05 . Atau dengan kata lain, hipotesis kedua $\left(\mathrm{H}_{2}\right)$ penelitian ini terdukung. Hal ini bearti bahwa penerapan whistleblowing system menjadi salah satu alat yang dapat dipergunakan untuk mencegah kebocoran-kebocoran pajak yang dilakukan oleh fikus. Hal ini dilakukan dalam rangka mencegah dan melakukan deteksi dini atas pelanggaran yang mungkin terjadi di lingkungan Direktorat Jenderal Pajak (DJP) melalui peningkatan peran pegawai serta masyarakat sevara aktif untuk menjadi pelapor pelanggaran (Peraturan Direktur Jenderal Pajak Nomor PER-22/PJ/, 2011); (Sulistyowati \& Pahlevi, 2018). Lebih lanjut (Peraturan Direktur Jenderal Pajak Nomor PER-22/PJ/, 2011); (Sulistyowati \& Pahlevi, 2018) menyatakan bahwa whistleblowing system juga memiliki tujuan untuk membangun kembali kepercayaan publik pada Direktorat Jenderal pajak serta mengajak seluruh pegawai Direktorat Jenderal Pajak untuk mengubah budaya permisif menjadi budaya korektif. Hal ini berari Direktorat Jenderal Pajak tidak akan pernah mentolerir adanyanya pelanggaran dengan cara melaporkannya ke saluran pengaduan yang telah disediakan. Pernyataan ini juga didukung oleh (Khulsum, 2014), whistleblowing system berpengaruh terhadap kepatuhan wajib pajak.

Gambar 2 juga menunjukan risiko sanksi pajak tidak memoderasi pengaruh antara good governance maupun whistleblowing system terhadap kepatuhan wajib pajak. Hal ini ditunjukan dengan nilai signifikasi yang lebih besar dibandingkan 0,05. Atau dengan kata lain, hipotesis ketiga $\left(\mathrm{H}_{3}\right)$ dan hipotesis keempat $\left(\mathrm{H}_{4}\right)$ penelitian ini tidak terdukung. Signifikasi risiko sanksi pajak pada pengaruh good governance terhadap kepatuhan wajib pajak adalah $(0,40)$. Sedangkan, signifikasi risiko sanksi pajak terhadap pengaruh whistleblowing system pada kepatuhan wajib pajak adalah $(0,36)$. Hal ini karena sanksi perpajakan merupakan alat pencegah agar wajib pajak tidak melanggar norma perpajakan. Sehingga, penerapan sanksi pajak dapat dapat membuat wajib pajak bersikap patuh. Hal ini karena wajib pajak akan memikirkan besarnya sanksi yang akan diterima ketika wajib pajak tidak patuh (Pujiwododo, 2016); (Sulistyowati \& Pahlevi, 2018). Menurut (Siringoringo, 2015), kepatuhan wajib pajak masih perlu ditingkatan dengan mendorong pelaksanaan perpajakan yang transparan. Transparan dalam hal ini meliputi pengeolaan pajak disegala bidang, baik bidang administrasi maupun pengelolahan dana yang bersumber dari sektor pajak.

Penyebab risiko sanksi pajak tidak memoderasi pengaruh good governance dan whistleblowing system terhadap kepatuhan wajib pajak, mungkin risiko sanksi pajak adalah variabel independen bukan variabel moderisasi. Hal tersebut didukung oleh penelitian (Ardyanto \& Utaminingsih, 2014); (Susmiyatun \& Kusmutiyanto, 2014); (Mutia, 2014); (Purnamasari, Pratiwi, \& Sukirman, 2017); (Irmawati \& Hidayatulloh, 2019). Oleh karena itu, untuk mendukung pernyataan bahwa sanksi perpajakan adalah variabel independen, maka penelitian ini melakukan analisis lebih dalam. Hasil analisis lebih dalam disajikan pada gambar 4 . 


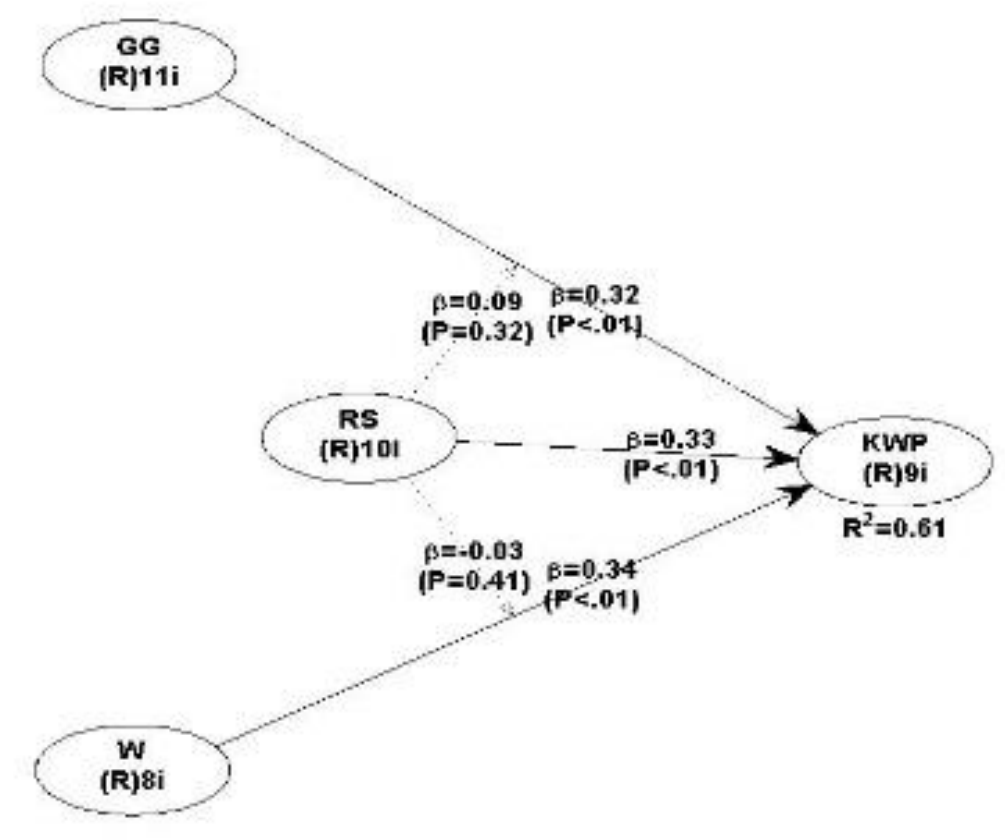

Gambar 4. Hasil Analisis Data Lanjutan

Sumber: data primer, diolah (2019)

Gambar 4 membuktikan bahwa risiko sanksi pajak adalah variabel independen. Hal ini ditunjukan nilai signifikasi $(<0,01)$ yang lebih kecil dibandingkan dengan 0,05. Sehingga, sanksi pajak merupakan alat pencegah agar wajib pajak tidak melanggar norma perpajakan. Wajib pajak akan mempertimbangkan sanksi yang akan diterima ketika wajib pajak melanggar undang-undang perpajakan maupun tidak membayar pajak (Pujiwododo, 2016); (Sulistyowati \& Pahlevi, 2018).

\section{SIMPULAN}

Kepatuhan wajib pajak dipengaruhi oleh good governance, whistleblowing sytem, dan risiko sanksi. Dengan penerapan sistem pemerintah yang baik, maka akan diikuti dengan meningkatnya kepatuhan wajib pajak. Salah satu alat yang digunakan oleh fiskus untuk mencegah kebocoran-kebocoran pajak adalah whistleblowing system. Whistleblowing system digunakan dalam rangka mencegah dan melakukan deteksi dini atas pelanggaran yang mungkin terjadi di lingkungan Direktorat Jenderal pajak (DJP). Selain itu, whistleblowing sytem juga bertujuan untuk membangun kembali kepercayaan public pada Direktorat Jenderal pajak serta mengajak seluruh pegawai Direkrorat Jenderal Pajak untuk mengubah budaya permisif menjadi budaya korektif, yaitu budaya yang tidak mentolerir adanya pelanggaran dengan melaporkannya ke saluruan pengaduan yang telah disediakan.

Risiko sanksi pajak tidak memoderasi pengaruh good governance dan whistleblowing system terhadap kepatuhan wajib pajak. Hal ini karena risiko sanksi pajak merupakan salah satu variabel independen yang dapat memengaruhi kepatuhan wajib pajak. Sanksi pajak merupakan salah satu alat pencegah agar wajib pajak tidak melanggar norma perpajakan. Sanksi pajak akan menjadi salah satu pertimbangkan wajib pajak ketika wajib pajak bersikap tidak patuh. 
Keterbatasan yang dimiliki oleh penelitian ini adalah validitas internal yang rendah seperti keterbatasan yang melekat pada metode survei. Selain itu, responden dalam penelitian ini belum mencakup mewakili seluruh propinsi di Indonesia. Sehingga, penelitian selanjutnya dapat menggunakan metode kualitatif untuk memperoleh validitas internal yang tinggi, dan penelitian selanjutnya dapat menggunakan responden yang mewakili seluruh propinsi di Indonesia..

\section{REFERENSI}

APBN. (2018). Retrieved from www.kemenkeu.go.id

Ardyanto, A. A., \& Utaminingsih, N. S. (2014). Pengaruh Sanksi Pajak dan Pelayanan Aparat Pajak Terhadap Kepatuhan Wajib Pajak Dengan Preferensi Risiko Sebagai Variabel Moderasi. Accounting Analisys Journal, 3(2), 220-229.

Fahmi, Y. (2018, November 26). Vonis 29 Tahun Penjara Gayus Tambunan Yang Tak Membuat Jera. Www.Liputan6.Com. Retrieved from https://www.liputan6.com/news/read/3230583/vonis-29tahun-penjara-gayus-tambunan-yang-tak-membuat-jera

Irmawati, J., \& Hidayatulloh, A. (2019). Determinan Kepatuhan Wajib Pajak UMKM di Kota Yogyakarta. Jurnal Sistem Informasi, Keuangan, Auditing Dan Perpajakan, 3(2), 112-121.

Karnedi, N. F., \& Hidayatulloh, A. (2019). Pengaruh Kesadaran Perpajakan, Sanksi Pajak dan Tax Amnesty Terhadap Kepatuhan Wajib Pajak Orang Pribadi. 12(1), 1-9. https://doi.org/10.22441/profita.2019.v12.01.001

Kembaren, B. S., \& Gunandi. (2013). Pengaruh Penerapan Good Governance Dalam Pelayanan Pajak Terhadap Kepatuhan Wajib Pajak Pada Kantor Pelayanan Pajak Pratama Cakung Dua (Universitas Indonesia). Retrieved from http://lib.ui.ac.id/naskahringkas/2015-09/S45931-Boris Sembiring Kembaren

Khaerunnisa, I., \& Wiratno, A. (2014). Pengaruh Moralitas Pajak, Budaya Pajak, Dan Good Governance Terhadap Kepatuhan. Jurnal Riset Akuntansi Dan Perpajakan, 1(2), 211-224.

Khulsum, A. (2014). Analisis Whistleblowing System Direktorat Jenderal Pajak Untuk Mengoptimalkan Penerimaan Pajak (Studi pada Kantor Pelayanan Pajak Pratama Surabaya Sawahan). Jurnal Akuntansi Unesa, 3(1), 1-25.

Laporan Kinerja Direktorat Jendral Pajak. (2017). Retrieved from http://www.pajak.go.id/laporan-kinerjatahun-2017-direktorat-jenderal-pajak\%0A\%0AM

Mangoting, Y., \& Sadjiarto, A. (2013). Pengaruh Postur Motivasi Terhadap Kepatuhan Wajib Pajak Orang Pribadi. Jurnal Akuntansi Dan Keuangan, 15(3), 106-116.

Mardiasmo. (2009). Perpajakan, Edisi Revisi 2009. Yogyakarta: Andi Offset.

Mardiasmo. (2016). Perpajakan. Yogyakarta: Andi Offset

Mutia, S. P. T. (2014). Pengaruh Sanksi Perpajakan, Kesadaran Perpajakan, Pelayanan Fiskus, dan Tingkat Pemahaman Terhadap Kepatuhan Wajib Pajak Orang Pribadi (Studi Empiris pada Wajib Pajak Orang Pribadi terdaftar di KPP Pratama Padang). Universitas Negeri Padang. 
Pebrina, R., \& Hidayatulloh, A. (2020). Pengaruh penerapan e-spt, pemahaman peraturan perpajakan, sanksi perpajakan, dan kualitas pelayanan terhadap kepatuhan wajib pajak. Jurnal IImiah Ekonomi Dan Bisnis, 17(1), 1-8.

Peraturan Direktur Jenderal Pajak Nomor PER-22/PJ/2011 Tentang Kewajiban Melaporkan Pelanggaran dan Penanganan Pelanggaran (Whitleblowing) di Lingkungan Direktorat Jenderal Pajak.

Peraturan Menteri Pendayagunaan Aparatur Negara dan Reformasi Birokrasi Republik Indonesia No 20 Tahun 2010 Tentang Road Map Reformasi Birokrasi 2010-2014.

Peraturan Pemerintah Nomor. 101 Tahun 2000 Tentang Pendidikan dan Pelatihan Jabatan Pegawai Negeri Sipil.

Pujiwododo, D. (2016). Persepsi Sanksi Perpajakan Terhadap Kepatuhan Wajib Pajak Orang Pribadi. Jurnal Online Insan Akuntan, 1(1), 92-116.

Purnamasari, A., Pratiwi, U., \& Sukirman, S. (2017). Pengaruh Pemahaman, Sanksi Perpajakan, Tingkat Kepercayaan Pada Pemerintah dan Hukum serta Nasionalisme Dalam Kepatuhan Wajib Pajak Membayar PBB-P2. Jurnal Akuntansi Dan Auditing, 14(1), 22. https://doi.org/10.14710/jaa.14.1.22-39

Purwono, H. (2010). Peraturan Pemerintah Nomor. 101. Jakarta: Airlangga.

Putra, D. A. (2018, November 26). Sri Mulyani Malu Tax Ratio RI Rendah. Www.Merdeka.Com. Retrieved from https://www.liputan6.com/bisnis/read/3611841/sri-mulyani-malu-tax-ratio-ri-rendah

Putra, I. N. T. A., \& Ni Ketut Lely Aryani. (2018). Pengaruh Tax Amnesty dan E-Filing pada Kepatuhan Wajib Pajak Orang Pribadi di Kabupaten Badung Fakultas Ekonomi dan Bisnis Universitas Udayana ( Unud ), Bali , Indonesia Fakultas Ekonomi dan Bisnis Universitas Udayan. E-Jurnal Akuntansi Universitas Udayana, 24, 2121-2147.

Siringoringo, W. (2015). Pengaruh good governance dan whistle blowing system terhadap kepatuhan wajib pajak orang pribadi dengan resiko sanksi pajak sebagai veriabel moderating (studi empiris terhadap wajib pajak orang pribadi di Kota Bekasi). Jurnal Akuntansi, 19(2), 207-224.

Sulistyowati, S. L., \& Pahlevi, R. W. (2018). Pengaruh Good Governance Dan Whistleblowing System Terhadap Kepatuhan Wajib Pajak Dengan Risiko Sanksi Pajak Sebagai Moderasi (Studi Empiris Pada Wajib Pajak Di Kabupaten Sleman). Jurnal Bisnis Teori Dan Implementasi, 9(1), 46-57.

Susmiyatun, \& Kusmutiyanto. (2014). Pengaruh Pengetahuan Perpajakan, Ketegasan Sanksi Perpajakan dan Keadilan Perpajakan terhadap Kepatuhan Wajib Pajak UMKM di Kota Semarang. Accounting Analysis Journal, 3(3), 378-386. https://doi.org/ISSN: 2252-6765

Undang-undang Nomor 28 Tahun Tentang Ketentuan Umum dan Tata Cara Perpajakan 